\title{
A Conglomerate of Pathology in Placental Disorders
}

\author{
Gudeli Vahini ${ }^{1}$ and I.V.Renuka ${ }^{2 *}$ \\ 'Dept of Pathology, Asram Medical College, Eluru, India \\ ${ }^{2}$ Dept of Pathology, NRI medical college, Chinakakani, Guntur, India
}

\begin{abstract}
Background: There is a vast diversity in placental pathology and several factors contribute to this diversity. A detailed placental examination is mandatory to assess any disorder and predict fetal outcome.
\end{abstract}

Aims and objectives: To study the placental pathology in various maternal, fetal and placental disorders and also the fetal outcome in these conditions.

Materials and Methods: A one and a half year prospective study of fifty consecutive placentae was done. A proforma was prepared with relevant clinical details. Maternal, fetal, placental risk factors were analyzed along with gross and microscopic lesions. Appropriate sections were taken from representative sites and Hematoxylin and eosin, Periodic acid Schiff stains were done.

Results: Out of fifty cases of placentae studied, forty seven cases (94\%) showed evidence of pathology associated with maternal, fetal and placental risk factors, either singly or in combination. Maternal risk factors were twenty five cases $(50 \%)$ of which the highest percentage being pregnancy related $(84 \%)$. Grossly infarcts and retro placental hematomas were common findings. Histological features of accelerated maturation were lesions commonly seen in these cases. In cases where the fetal outcome was poor like in abortions, intrauterine fetal death and still births all (100\%) placentae were abnormal.

Conclusions: In this study high percentage of placentae showed evidence of pathology, the majority of which were associated with maternal, fetal or placental risk factors either singly or in combination. Those cases in which fetal outcome were poor all the placentae were abnormal. A careful examination of placentae is required as it is a clue for various diseases and to determine fetal outcome. Histopathological examination of both gross and microscopy proved to be valuable tools in determining placental pathology.

\section{Keywords: Placenta, Pathology, Fetal, Maternal}

\section{Introduction}

Pathology of placenta has been steadily increasing. Several factors have contributed to this increase. Delayed child bearing and infertility are common in the day and age. When pregnancies fail or there is unexpected outcome, those involved want an explanation and assessment of future risks. There is now recognition in that placental examination will often yield valuable information for the patients. This is a prospective one year six months study of fifty consecutive placentae.

\section{Materials and Methods}

A special proforma was prepared recording the relevant clinical details of the mother, along with fetal gestation, age and fetal outcome. Maternal, fetal and placental risks factors were analyzed and various gross, microscopic lesions encountered with these risks factors were studied. The placentae were weighed and dimensions noted. The fetal, maternal surface, cut section of cord and membranes were examined and appropriate sections taken. Hematoxylin and eosin (H\&E) stains were used in routine cases. Special stains like Periodic Acid Schiff (PAS) was necessary to assess thickening of the basement membrane and Masson's Trichrome to assess stromal fibrosis.

\section{Results}

Maternal, fetal and placental risk factors were studied. The majority of cases 47 (94\%) were associated with some risk factor, either singly or in combination and a very low number, three $(6 \%)$ of cases had no associated risk factors. This group was followed by the category of only maternal risk factors 25 cases (50\%), the majority of which were pregnancy related (84\%), mainly PIH along with oligohydramnios, abruptio placentae, preeclampsia, ante partum eclampsia, molar pregnancy, abortion, prematurity and post maturity. This was followed by a combination of pregnancy related and general risk factors. Four cases $(16 \%)$ were identified with diabetes, hypertension and anemia (Tables 3,4 \&5). Next came the group of only placental risk factors 12 cases $(24 \%)$ and lastly came the category of 10 cases $(20 \%)$ fetal risk factors (Tables $1 \& 2$ ). The commonest gross and microscopic lesions encountered in the placenta were infarcts and features of accelerated maturation like syncytial knots, chorangiosis, microscopic infarcts, fibrinoid change and vascular congestion, stromal 
fibrosis and varied cytotrophoblastic maturation.

In placentae, where the fetal outcome was abortion, most of the cases did not show significant gross pathology. Subchorial thrombosis (Brues' mole) was not seen. However, microscopically secondary changes were noted in 3 cases (Table 2).

In the cases where the fetal outcome was poor, prematurity, grossly retroplacental hematomas were seen in 1 case $(100 \%)$ and infarcts were also seen as the commonest macroscopic lesions, delayed maturation in $1(100 \%)$ case as the commonest microscopic lesion (Table 4).

General maternal risk factors were encountered either singly or in combination with other risk factors like Hypertension, diabetes, anemia and neurofibromatosis 4 cases $(16 \%)$ (Table 3\&4).
Most of the placentas however, did not show any significant gross pathology except for the placenta of diabetes. This was a large placenta and showed villous edema and chorangiosis. An analysis between the presence of placental pathology and fetal outcome was poor in abortion, intrauterine fetal death with maceration and intrauterine growth retardation (10 cases) $(100 \%)$ of the placentae were abnormal in these cases (Table 2 ).

In preterm and in post term deliveries 100\% were abnormal. Macroscopically the commonest lesions seen were infarcts and retroplacental hematoma in $100 \%$ cases, microscopically chorioamnionitis was seen as a secondary change. A thorough examination of the placenta contributes significantly towards determining the cause of poor fetal outcome as it is a mirror of not only pure placental pathology, but various maternal and fetal risk factors.

Table 1: Primary placental causes for placental Pathology:

\begin{tabular}{|l|l|l|l|l|l|}
\hline S.No. & Risk factor & No. of Cases & Macroscopy & Cord & Microscopy \\
\hline 1. & $\begin{array}{l}\text { Placenta } \\
\text { accreta }\end{array}$ & 2 & $\begin{array}{l}\text { Bulky uterus with products with } \\
\text { placenta accreta, foci of increta. }\end{array}$ & $\begin{array}{l}\text { Centrally } \\
\text { placed }\end{array}$ & $\begin{array}{l}\text { Products of conception, tertiary } \\
\text { villi, decidual tissue, and necrosis. }\end{array}$ \\
\hline 2. & $\begin{array}{l}\text { Placental } \\
\text { Chorangioma }\end{array}$ & 2 & $\begin{array}{l}\text { Dome shaped elevated nodule } \\
\text { of } 8 \text { cm on fetal surface }\end{array}$ & $\begin{array}{l}\text { Centrally } \\
\text { placed }\end{array}$ & $\begin{array}{l}\text { Chorangiosis,Dome shaped with } \\
\text { muliple capillary sized blood } \\
\text { vessels. }\end{array}$ \\
\hline 3. & $\begin{array}{l}\text { Battledore } \\
\text { and Triradiate } \\
\text { placenta }\end{array}$ & 2 & $\begin{array}{l}\text { Battledore \& triradiate placenta } \\
\text { with peripheral calcification, }\end{array}$ & $\begin{array}{l}\text { Eccentrically } \\
\text { placed }\end{array}$ & $\begin{array}{l}\text { Vascular congestion, fibrinoid } \\
\text { change }\end{array}$ \\
\hline 4. & $\begin{array}{l}\text { Retroplacental } \\
\text { clot }\end{array}$ & 2 & $\begin{array}{l}\text { Infarct on maternal \& fetal } \\
\text { surface retroplacental clot on } \\
\text { maternal surface }\end{array}$ & $\begin{array}{l}\text { Centrally } \\
\text { placed }\end{array}$ & $\begin{array}{l}\text { Placental infarct Calcification, } \\
\text { Tenney-Parker lesions, }\end{array}$ \\
\hline 5. & $\begin{array}{l}\text { Calcified } \\
\text { placenta }\end{array}$ & 2 & $\begin{array}{l}\text { c/s- A small infarct, multiple } \\
\text { calcified areas }\end{array}$ & $\begin{array}{l}\text { Eccentrically } \\
\text { placed }\end{array}$ & $\begin{array}{l}\text { Infarct with fibrosis extensive areas } \\
\text { of } \\
\text { dystrophic calcification. }\end{array}$ \\
\hline 6. & Placenta previa & 2 & Appears normal & $\begin{array}{l}\text { Centrally } \\
\text { placed }\end{array}$ & $\begin{array}{l}\text { Placental infarct Calcification, } \\
\text { Tenney- Parker lesions }\end{array}$ \\
\hline
\end{tabular}

Table 2: Foetal causes for placental Pathology

\begin{tabular}{|l|l|l|l|l|l|}
\hline S.No. & Foetal outcome & $\begin{array}{l}\text { No. of } \\
\text { cases }\end{array}$ & Macroscopy & $\begin{array}{l}\text { Weight of placenta } \\
\text { and cord insertion }\end{array}$ & Microscopy \\
\hline 1. & ABORTION & 3 & $\begin{array}{l}\text { Maternal surface showed } \\
\text { multiple infarcts }\end{array}$ & $\begin{array}{l}450 \text { gms centrally } \\
\text { placed }\end{array}$ & $\begin{array}{l}\text { Chorangiosis, hyalinization, } \\
\text { and Multiple infarcts }\end{array}$ \\
\hline 2. & $\begin{array}{l}\text { IUFD WITH } \\
\text { MACERATION }\end{array}$ & 2 & Placenta with fetus & $\begin{array}{l}\text { 250gms Centrally } \\
\text { placed }\end{array}$ & $\begin{array}{l}\text { Acute deciduitis, Maternal } \\
\text { floor infarction }\end{array}$ \\
\hline 3. & $\begin{array}{l}\text { IUD with } \\
\text { Thalassemia major } \\
\text { in first child }\end{array}$ & 2 & $\begin{array}{l}\text { Placenta with fetus Umbilical } \\
\text { cord- one artery and one } \\
\text { vein. }\end{array}$ & $\begin{array}{l}\text { 200gms } \\
\text { Eccentrically placed } \\
\text { cord, }\end{array}$ & $\begin{array}{l}\text { chorangiosis, Syncitial knots, } \\
\text { hemorrhagic infarcts. }\end{array}$ \\
\hline 4. & $\begin{array}{l}\text { Intra uterine } \\
\text { growth retardation } \\
\text { (IUGR) }\end{array}$ & 2 & $\begin{array}{l}\text { Maternal surface shows a } \\
\text { focus of white areas. Umbilical } \\
\text { cord -2 vessels one vessel } \\
\text { atrophic }\end{array}$ & 530gms Para centric & $\begin{array}{l}\text { Whitish focal area on maternal } \\
\text { surface, fibrinoid deposition, } \\
\text { calcification }\end{array}$ \\
\hline 5. & $\begin{array}{l}\text { TWIN } \\
\text { PREGNANCY }\end{array}$ & 1 & $\begin{array}{l}\text { Centrally placed } 2 \text { umbilical } \\
\text { cords. Monochorionic } \\
\text { diamniotic type }\end{array}$ & $\begin{array}{l}\text { Centrally placed } \\
\text { cord }\end{array}$ & $\begin{array}{l}\text { plenty of vacuolated cells on } \\
\text { fetal surface membranes }\end{array}$ \\
\hline
\end{tabular}


Figure 3: Maternal causes for Placental Pathology

\begin{tabular}{|l|l|l|l|l|l|}
\hline S.No. & Risk factors & $\begin{array}{l}\text { No.of } \\
\text { cases }\end{array}$ & Macroscopy & $\begin{array}{l}\text { Weight of placenta } \\
\text { and Cord insertion }\end{array}$ & Microscopy \\
\hline 1. & $\begin{array}{l}\text { Hypertension } \\
\text { and Diabetes }\end{array}$ & 1 & $\begin{array}{l}\text { Multiple infarcts on } \\
\text { maternal surface. } \\
\text { Fetal surface showing } \\
\text { hemorrhages. }\end{array}$ & $\begin{array}{l}900 \text { gms Centrally } \\
\text { placed }\end{array}$ & $\begin{array}{l}\text { Increased vascularity to } \\
\text { chorangiosis, Syncitial spouts, } \\
\text { stem vessels show hyperplasia , } \\
\text { narrowing of lumen }\end{array}$ \\
\hline 2. & Preeclampsia & 1 & $\begin{array}{l}\text { Multiple infarcts on } \\
\text { maternal surface. } \\
\text { Amnionic nodosum,Vernix } \\
\text { caseosa. Retroplacental } \\
\text { hematoma }\end{array}$ & $\begin{array}{l}\text { 300gms Centrally } \\
\text { placed }\end{array}$ & $\begin{array}{l}\text { Multiple infarcts, hemorrhagic } \\
\text { infarct with ischemic necrosis, } \\
\text { calcifications Atrophic tertiary } \\
\text { villi , concentric hypertrophy, } \\
\text { Tenney-Parker change, }\end{array}$ \\
\hline
\end{tabular}

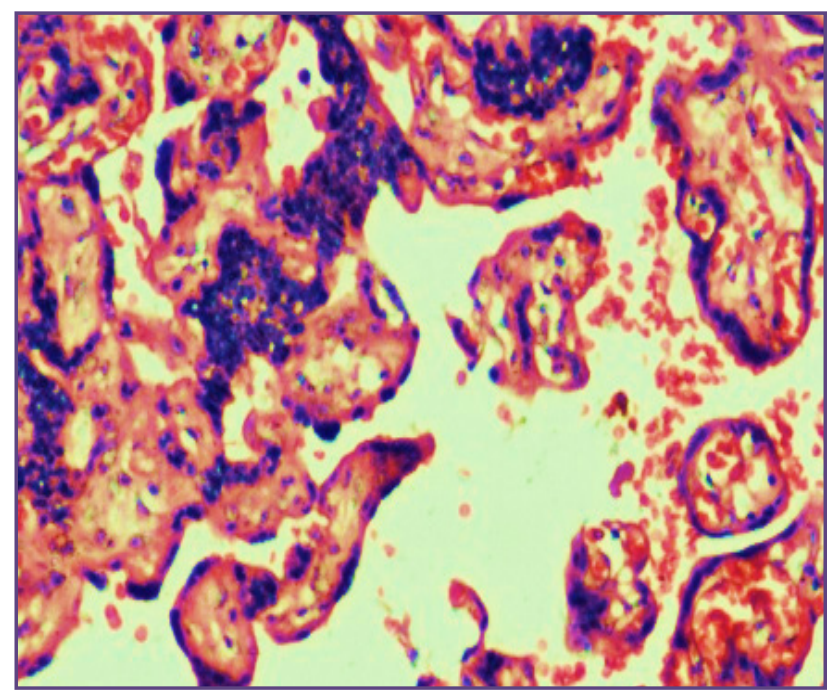

Fig. 1: Tenny parker changes in placenta in PIH (Haematoxylin Eosin stain X100).

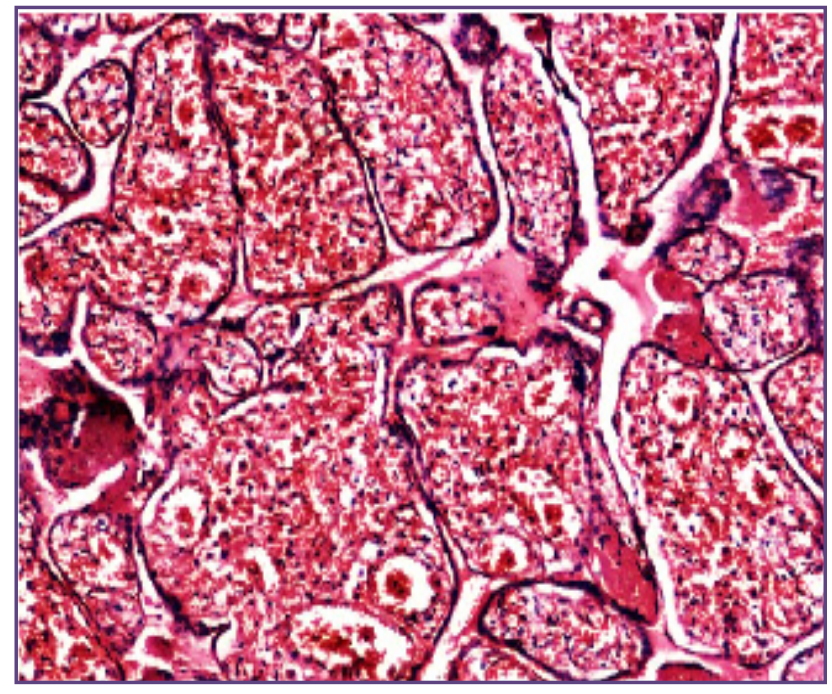

Fig. 3: Shows Chorangiosis of placenta ( Haematoxylin Eosin stain X100).

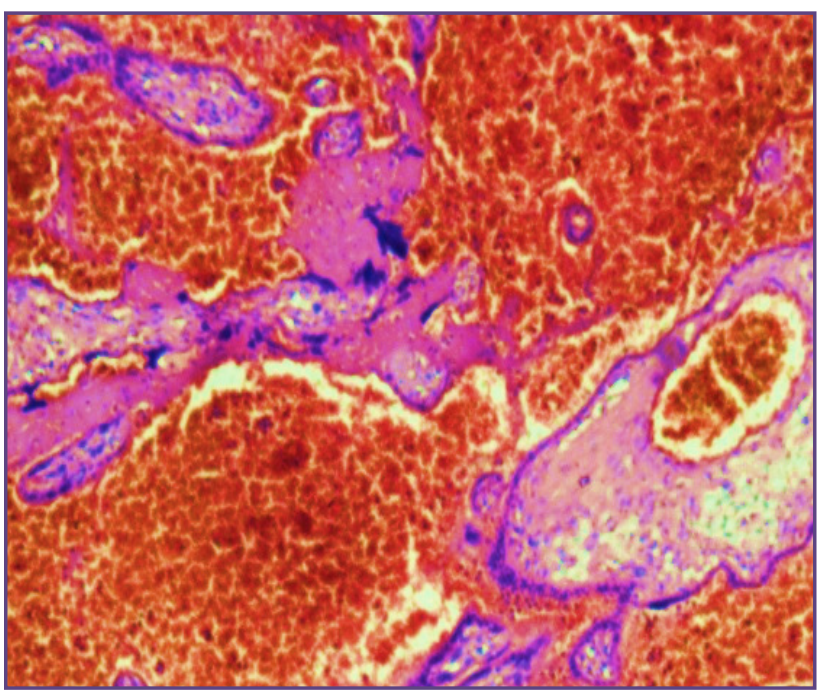

Fig. 2: Hemorrhagic areas in placenta (Haematoxylin Eosin Stain X100).

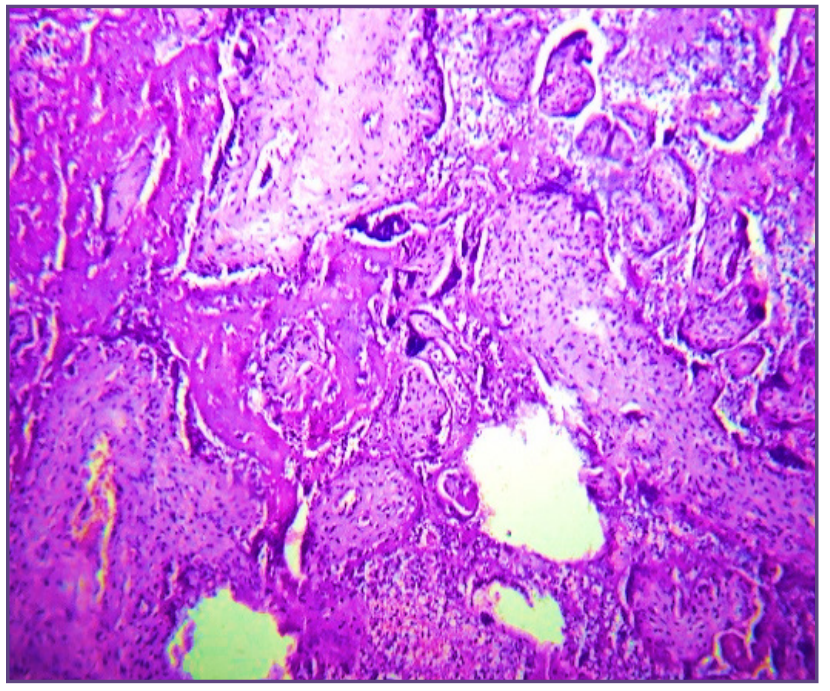

Fig. 4: Fibrinoid change in villi (Haematoxylin Eosin stain X100). 


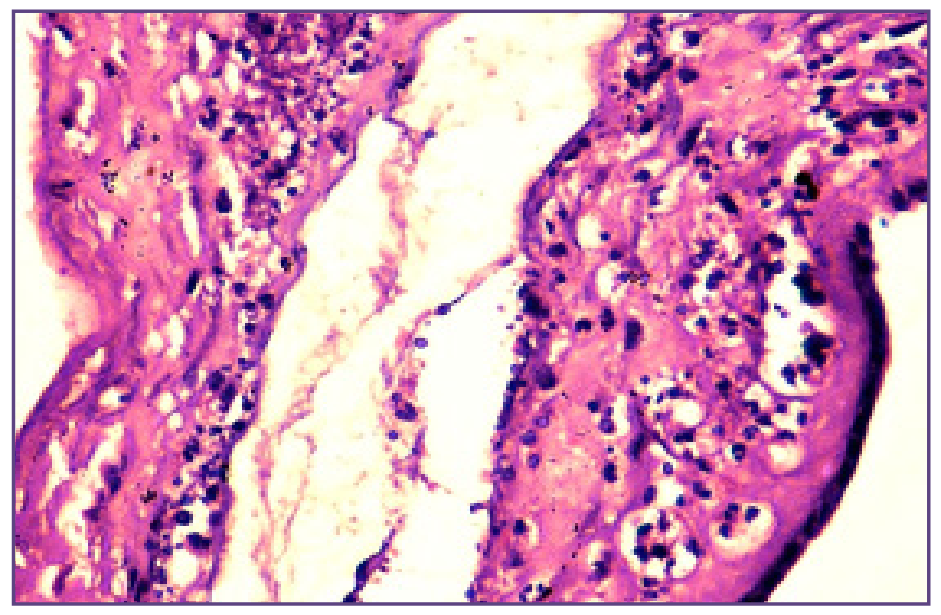

Fig. 5: Membranes showing acute Chorioamnionitis (Haematoxylin Eosin stain X100).

\section{Discussion}

Our study was a one year six months prospective study which included fifty consecutive placentae. The majority 47 cases $(97 \%)$ were associated with some risk factors, either singly or in combination. Our figure of $97 \%$ is higher than the percentage of Avasthi et al [1] from Ludhiana, Punjab whose study included $80 \%$ cases with some associated risk factor. We further categorized this group into those having only maternal, fetal and only placental risk factors 43 cases $(86 \%)$. This group was followed by the category of only maternal risk factors 25 cases $(50 \%)$, majority of these were pregnancy related $(86 \%)$ and general risk factors were just 4 cases $(8 \%)$.Next came the group of only placental risk factors 12 cases $(25 \%)$ and lastly came category of fetal risk factors 10 cases $(20 \%)$. In the study of Avasthi et al $55.6 \%$ showed maternal risk factors. This figure is much higher than ours of $25 \%$. These authors found that the percentage of pregnancy related risk factors was higher than the general risk factors $(71.4 \%$ and $28.6 \%)$ respectively. These findings are similar to ours except that our corresponding figures were higher (86\% and $8 \%$ ). In the category of pregnancy related risk factors, PIH headed the list $(28 \%)$ it formed $14 \%$ of the total risk factors this figure is higher than that of Avasthi et al 5.32\% who also encountered PIH most frequently. PIH was followed by abruptio placentae (12\%) and oligohydramnios (8\%). The other risk factor they found in this group were Abortions $(8 \%)$, molar pregnancy $(8 \%)$, prematurity $(4 \%)$ and post maturity (4\%).

In the cases of $\mathrm{PIH}$ including preeclampsia, eclampsia 7 cases $(100 \%)$ the commonest macroscopic lesions encountered were infarcts. Our findings are consistent with those of other authors Salafia et al [2] who also found a higher percentage of infarction $68.4 \%$ in their cases of preterm eclampsia and Das et al [3] encountered infarction in $51.4 \%$ of their cases with preeclampsia and eclampsia. Similar finding was noted by Bandana Das et al in 1996 where they showed an increased finding of infarction in cases of PIH[9]. Udainia et al in 2004 had also observed an increase in the incidence of placental infarction with severity of toxaemia[10]. Naeye and friedman in 1979 calculated that $70 \%$ of the excess foetal deaths in women with hypertension are due to large placental infarcts and markedly small placental size[11]. Retroplacental hematoma was the next common gross lesion encountered by us $(58 \%)$. This percentage is higher than that of Salafia et al [2] (12\%) and Das et al [3] (8.75\%) .Fox in 1995[12] and Mohan et al in 1989 [13]reported higher incidence of retroplacental hematoma in preeclampsia. The increase in placental infarcts, retroplacental hematoma and calcification was also noted in the study by sodhis et al in 1990 and these findings correlated well with severity of maternal disease[14].

The commonest microscopic features encountered in $\mathrm{PIH}$ were features of accelerated maturation. Increased syncytial knots were seen in $100 \%$ cases. This figure is considerably higher than $32 \%$ reported by Avasthi et al and $40 \%$ reported by Salafia et al $[2,3]$. Vascular congestion was also seen in $42 \%$ ( 3 cases), much lower than the $72 \%$ figure of

Salafia et al [2]. Obliterans endarteritis of the fetal stem vessels was seen in $25 \%$ cases, which is comparable to the $25 \%$ of W Joshi et al [4]. Histological confirmation of the $100 \%$ ( 7 cases) of infarction as seen in all the 7 cases noted grossly showed microscopic infarction. 100\% cases showed infarction both gross and microscopic which is more than half of the number of cases detected by Salafia et al [2] (49\%) in association with abruptio placentae. $65 \%$ cases showed retroplacental hematoma on gross which was confirmed microscopically. 
As far as the other maternal pregnancy related risk factors were concerned we found majority of abortion cases showed no lesions on gross examination and some authors recorded a single case of Subchorial thrombosis (Brues' mole) a feature which has been described in association with abortion and may play a role in the cause- Shanklin and Scott [5]. Microscopically changes secondary to fetal death like chorangiosis, fibrinoid change, hyalinization and infarction were seen in $100 \%$ cases though $30.76 \%$ showed normal villi as described by Fox [6].

In the cases of prematurity (4\%) microscopically deciduitis, fibrinoid material entrapped in villi, smooth muscle hyperplasia of small sized stem vessels, syncytial spouts and infarction were seen.

The least commonly encountered risk factor was post maturity (4\%). This figure is lower than the $8 \%$ of Avasthi et al[1]. We found retroplacental hematoma on macroscopic examination and microscopically found perivillous fibrinoid deposition, maternal floor infarction, chorangiosis and Tenny Parker changes on microscopy $(100 \%)$ as described by V.V. Joshi et al[4].

We divided the 50 cases into various groups depending upon fetal outcome abortions (6\%), IUFD with maceration $(2 \%)$, preterm delivery ( $2 \%$ ),post maturity ( $2 \%$ ) and analyzed the relationship between the presence of placental pathology and fetal outcome. These were associated with $100 \%$ abnormal placenta and correlated with poor fetal outcome. The gross and microscopic pathology of the placenta with poor fetal outcome was further analyzed and compared with a cohort group. In the former abortion $(6 \%)$ formed the largest group, followed by IUFD with maceration (2\%), IUD (2\%), IUGR (2\%) and twin pregnancy was encountered in (2\%). In cases of IUFD with maceration, the commonest gross lesion was infarction and retroplacental hematoma in $100 \%$ cases which was confirmed on histology. Microscopically however the commonest lesions were changes secondary to IUFD like Infarction on maternal surface, fibrinoid deposition, calcification, maternal floor infarction, vascular congestion to chorangiosis $(100 \%)$ cases. The study of Avasthi et al [1] found with a lower percentage of microscopic infarction (15\%) and a lower percentage of fibrinoid change. However they found a higher percentage of increased syncytial knotting (50\%). In the study of Fox etal [6] cytotrophoblastic hyperplasia was seen in almost $100 \%$ cases. The incidence of maternal floor infarction in IUFD in our study was $100 \%$ higher than $40 \%$ of Andres et al [7] and $17 \%$ of Naeye et al [8]. We had $20 \%$ of IUGR which is higher than the $8 \%$ of Avasthi et al [1] and 7.6\% of Salafia et al [2]. We also found evidence of maternal floor infarction which was described in all cases of IUGR. Microscopically, cytotrophoblastic hyperplasia with basement membrane thickening was found most frequently in $100 \%$ cases and villous hypovascularity which showed fibrosis in $100 \%$ cases which is higher compared with the percentage of Avasthi et al[1]. The study of Salafia et al [2] also found the latter lesions in $50 \%$ cases.

\section{Conclusions}

In our study majority of the placentae were abnormal and associated with wide variety of risk factors either alone or in combinations. A careful examination of placenta both gross and microscopy yielded a valuable clue to these risk factors. It was especially of great importance in cases where the fetal outcome was poor, preterm and post term deliveries. It is mandatory to examine every placenta after delivery for the proper management of mother and baby with risk factors.

\section{Abbreviations}

PIH-Pregnancy induced hypertension, IUGR-Intrauterine growth retardation, IUD-Intrauterine death, IUFDIntrauterine fetal death, CAM-Chorioamnionitis

\section{References}

1. Avasthi K, Micha U. histopathology of placenta and its correlation with fetal outcome.J Obstetric Gynaecol Ind 1991;41:317.

2. Salafia C, Pezznlto J. Placental pathologic features of preterm eclampsia. Am J Obstetric Gynaecol 1995;173:1097.

3. Das B,Dutta D.Placental morphology in hypertension disorders of pregnancy and its correlation with fetal outcome. J Obstetrics Gynaecol Ind 1996;45:230.

4. Joshi VV. Handbook of placental pathology. Igaku shon medical publisher 1994.

5. Shanklin DR,Scott JS .Massive subchorionic thrombohematoma (Brues' mole).Br J obstetric gynaecol $1975 ; 82: 476$

6. Fox H. Pathology of the Placenta. W.B. Saunders, Philadelphia, PA; 1978.

7. Andres R, Kuyper W. The association of maternal floor infarction of the placenta with adverse perinatal outcome. Am J Obstetr Gynaecol 1990;163:935.

8 Naeye R. Maternal floor infarct.Hum Pathol. 1985 Aug;16(8):823-8.

9 Bandana Das, D.Dutta, S.Chakraborthy,P.Nath.placental morphology in hypertensive disorders of pregnancy and its correlation with fetal outcome.J Obstet and Gynecol India, 1996;46(1):40-46. 
10 Udainia A,Bhagwat SS, Mehta CD.Relation between placental surface area,infarction and fetal distress in pregnancy induced hypertension with its clinical relevance.J Anat Soc Ind 2004,53;1:27-30.

11. Naeye RL,friedman EA.Causes of perinatal death associated with gestational hypertension and proteinuria.Am J obst and Gynaecol,1979;133:8-11.

12. Fox H.General pathology of placenta.obstetrics and gynaecological pathology ed.New york:Churchill livingstone;1995.page 1447-1508.

13. Mohan harsh,sodhis,Mohan PS,et al.Fetal correlation with placental pathology in toxaemia of pregnancy.J obstetrics and gynaecology India 1989;39:170-75.

14. Sodhi s,Mohan H,Jaiswal TS,Mohan PS,Rathee S.Placental pathology in pre-eclampsia eclampsia syndrome.Indian $\mathrm{J}$ Pathol Microbiol Jan 1990; 33(1):11-6.

*Corresponding author:

Dr I.V.Renuka, Professor, NRI medical college, Chinakakani, Guntur, India

Phone: +91 9949968294, 9848134166

Email: gudelivahini@gmail.com,repriya56@gmail.com

Financial or other Competing Interests: None. 